\title{
Private Higher Education: Themes and Variations in Comparative Perspective
}

\section{Philip G. Altbach \\ Philip G. Altbach is J. Donald Monan SJ professor of higher education and director of the Center for International Higher Education at Boston College.}

$\mathrm{P}$ rivate higher education has been thrust into the limelight at the end of the 20th century, largely because of the decline of the state sector. Governments are reluctant to spend public funds on postsecondary education while at the same time demands for access and skilled personnel remain high. Private institutions are providing both access and the skills needed for the economy of the 21 st century. Public institutions are being "privatized" as public funds shrink and universities are forced to find alternative sources of support. Public universities increasingly resemble private institutions in funding patterns. The idea of an academic degree as a "private good" that benefits the individual rather than a "public good" for society is gaining acceptance. The "logic" of today's market economies and an ideology of privatization have contributed to the resurgence of private higher education, and the establishment of private institutions where none existed before. In the former Soviet Union and in Central and Eastern Europe, private universities and specialized postsecondary institutions are the fastest-growing part of postsecondary education. Even China and Vietnam, which retain Communist regimes, are encouraging the growth of private postsecondary institutions.

\section{The nature and scope of private colleges and universities vary worldwide.}

The nature and scope of private colleges and universities vary worldwide. In much of Europe, postsecondary education is almost exclusively state supported, with only a very limited private sector-mainly comprised of religious institutions that provide theological education. Tuition is nominal, with virtually the whole higher education budget coming from the state. In East Asia-specifically, Japan, South Korea, the Philippines, and Taiwan - the private sector dominates higher education, enrolling 80 percent of the student population. Private institutions depend largely on tuition, and some, especially in the Philippines, are profit making. The most prestigious universities tend to be public, although a few top schools are private. In the United States, the balance between public and private has gradually shifted so that now 80 percent of students attend pub- lic universities and colleges. U.S. private universities are included among the most prestigious and most substantially endowed institutions. Nevertheless, a majority of U.S. private schools remain fully dependent on tuition for survival. In Latin America, the oldest universities are the private institutions founded by the Catholic Church, but the public sector has grown in the 20th century and dominates higher education in nearly all countries in the region. Africa has few private universities, and public institutions educate virtually all students.

\section{Private colleges and universities are of- ten small and face severe financial, en- rollment, and other problems-related in part to their size.}

The dispersion of private higher education institutions worldwide is impressive. In some countries, private institutions are the most prestigious, while in others they occupy the lower tiers of the hierarchy. Today they represent the fastest-growing segment of higher education. Although not widely recognized, private institutions dominate higher education in much of Asia. Recently, private universities have become a significant part of the academic systems of Latin America and now enroll a growing proportion of the student population. It is mainly in Western Europe and Africa that private institutions are relatively rare. In Western Europe, there is no significant trend toward the expansion of private universities, whereas in Central and Eastern Europe, private initiatives are showing the largest growth. While Africa has not experienced much expansion of the private higher education sector, it is likely that the World Bank and other multilateral agencies will stress privatization as a means of absorbing demands for access to postsecondary education.

Private colleges and universities are often small and face severe financial, enrollment, and other problems-related in part to their size. These institutions are for the most part ignored in the literature. We know little about their quality, their students, or their role in the wider system of higher education. An entirely new class of vocational private postsecondary institutions has emerged in many countries. Some of these institutions have official recognition, and some do not. This rapidly expanding sector deserves attention - particularly those institutions newly established in countries (such as Russia) that have only recently permitted private universities. What role do these 
institutions play in the higher education system? What are their missions and standards?

Financially, private colleges and universities depend for the most part on the students who pay tuition. But there are some variations: in some countries, private institutions receive financial support from the government. In India, for example, most undergraduates study in private colleges, which receive significant financial support from state governments via the universities to which the private colleges are affiliated. Private universities in Japan, the United States, and some other countries are eligible for various kinds of government support-in the U.S. system through student loans and support for research. Private schools also may have other sources of income. In the United States, the prestigious private universities and colleges have large endowments that provide income.

Private universities are at the same time
independent and autonomous, while
also being subject to a variety of exter-
nal controls. They are largely respon-
sible for their own funding, and the
consequences of poor financial manage-
ment are immediate and serious.

In most countries, private colleges and universities are nonprofit entities, although in some places profit-making academic institutions exist. In the United States and some other countries, such institutions are limited to the largely vocational "proprietary" sector-these schools are not usually evaluated by the postsecondary accrediting agencies. In a few countries, such as the Philippines, large universities can be listed on the stock exchange. Even in the United States, the new University of Phoenix, an entrepreneurial private university, is listed on the stock exchange as a profitmaking corporation and is at the same time accredited by the regional postsecondary accrediting authorities. The financial stability of private higher education varies tremendously - extending from Harvard University, perhaps the wealthiest university in the world, with its $\$ 6$ billion endowment, to many financially struggling small institutions constantly on the verge of bankruptcy. Indeed, private academic institutions regularly fail in many countries. Patterns of financial management, ownership, support, and corporate arrangements also show many differences.

Although there is much change now taking place, most private universities have nonprofit status worldwide. They are sponsored by religious organizations, philanthropic societies, or other kinds of service organizations. In some countries, including the United States, private colleges and universities operate under a nonprofit charter given by the state, which regulates the terms and conditions of this status. Such institutions are exempt from taxes and enjoy other privileges. In these cases, nonprofit universities are expected to serve broad educational and cultural goals. The ideals of service, education, and research lie at the heart of the nonprofit mission for higher education. Religious organizations may be concerned with providing a religious environment for education. Most older private universities are nonprofit institutions with a strong tradition of service to society.

Private universities are at the same time independent and autonomous, while also being subject to a variety of external controls. They are largely responsible for their own funding, and the consequences of poor financial management are immediate and serious. They have considerable autonomy over academic programs, majors, markets, and standards. Yet they are also accountable to external authorities, ranging from accrediting agencies in the United States to much stricter governmental regulation in such nations as Korea, Japan, and India.

In the United States, private colleges and universities are subject to a variety of external controls. If they accept any funds from government sources-in the form of student loans, research grants, contracts, and the like-they are subject not only to a variety of government regulations relating to the specific funding arrangements but also to a large number of other reporting and regulatory requirements. Private institutions are also accredited-a "voluntary" process coordinated by self-managed regional agencies that review and accredit all postsecondary institutions on a regular basis. Professional societies also accredit degree programs-from law and medicine to teacher educationas part of a separate review process.

\section{The market for education is exceedingly imperfect. It is hard to predict trends in employment, and even harder to ensure that institutional programs are relevant to these trends.}

Regulatory regimes are much more stringent in other parts of the world, especially in some Asian nations. In Korea, government agencies control academic salaries and other conditions of work in private universities. Private universities are also subject to control in matters of tuition charges, institutional expansion, and enrollments in specific departments and programs. Even when these regulations are imposed, the government does not necessarily 
provide significant funding for private higher education. Similarly, Indian universities - to which all private colleges must be affiliated-conduct end-of-term examinations, determine the outlines of the curriculum for most courses, dictate faculty salary levels, set minimum standards for student entry, and supervise libraries and other physical facilities of the affiliated colleges. Perhaps most important, the universities award all degrees. In the Indian case, a considerable portion of the budget of private colleges comes from government grants.

In most other countries private institutions are subject to less control than is the case in Korea or India. Indeed, in countries where the private sector has only recently expanded, controls are, not surprisingly, poorly developed. This often means that private institutions vary greatly in quality, orientation, and financial stability. This is especially the case in Central and Eastern Europe and in the former Soviet Union, where private institutions have proliferated in an environment characterized by a decline of public universities and a lack of supervision of the new private institutions.

\section{Private higher education, precisely be- cause of its rapid expansion and more central role in the world's higher edu- cation systems, faces special challenges and responsibilities.}

Private higher education is very much influenced by the market. Even the prestigious private universities in the Untied States and Japan must concern themselves with their reputation and their place among the other universities, both nationally and internationally. Less prestigious and newer private institutions must be even more concerned about market forces, competition from other educational institutions, trends in the employment market, and other factors. Serious miscalculation can jeopardize institutional survival.

The market for education is exceedingly imperfect. It is hard to predict trends in employment, and even harder to ensure that institutional programs are relevant to these trends. Vocationally oriented private institutions are directly involved in predicting labor markets and the specific needs for specialists. Private universities that focus on the traditional arts and science fields are more insulated from the direct labor market, but they are competing with other academic institutions, and are dependent on the market for university graduates.

The discipline of the market shapes private universi- ties. At the end of the 1990s, with an increased emphasis on education market forces generally, the ethos of private colleges and universities is spreading throughout the systems of all countries. There are, of course, costs and benefits to a purely market orientation in education. Traditionally, the university has provided education in a range of subjects and disciplines, not all of which might appeal to the market. The question of how basic research, which may not yield immediate results in the marketplace, will be supported remains to be answered if the academic system continues to move toward a stronger market orientation.

Private higher education, precisely because of its rapid expansion and more central role in the world's higher education systems, faces special challenges and responsibilities. The following issues need to be explored as the private sector moves to the center.

- What are the elements that make up private higher education? What kinds of institutions exist? What roles do they play in the higher education systems of their nations?

- Private higher education is largely market driven. To what extent should the market control developments? Should restraints be imposed? How do restraints work in countries where they exist?

- How should the older, established, and often high-status private universities relate to newer, less-well-endowed institutions? Do the former have a special responsibility to assist or monitor emerging universities?

- What is the appropriate balance of accountability and autonomy in the private sector of higher education?

- How should private higher education be accredited?

- What is the appropriate role for government in private higher education? How should public and private institutions relate to each other? Should private higher education be funded by public sources?

- What should the role of the new vocational postsecondary institutions be in the higher education system?

- In Latin America especially, but in other parts of the world as well, what role should the Roman Catholic Church, and other religious organizations, play in higher education? What responsibilities do religious universities have to the broader higher education system?

Private higher education is emerging as one of the most dynamic segments of postsecondary education at the turn of the 21st century. Its prominence is linked with the ideology of privatization that is so influential at present and with the trend worldwide to cut public spending. While private higher education has a long historical tradition, and in some countries is a dominant force, its new influence has caught the world of postsecondary education unprepared. This is an opportune time to focus attention on private higher education. 